\title{
Archaeopetrological approximation to the lithic procurement of the neolithic axes and adzes from Can Sadurní's cave (Begues, NE Iberian Peninsula)
}

\author{
Mar Rey-Solé ${ }^{1}$, Gemma Alías ${ }^{2}$, Mireia Ache ${ }^{3}$, Elicinia Fierro ${ }^{4}$, Manel Edo ${ }^{4}$, \\ Xavier Mangado ${ }^{1}$ \\ 1. Seminari d’Estudis i Recerques Prehistòriques, Dept. Prehistòria, Història Antiga i Arqueologia, Universitat \\ de Barcelona, C/Montalegre, 6, 08001, Barcelona, Spain. Email: Rey-Solé: mreysole@ub.edu; \\ Mangado: mangado@ub.edu \\ 2. Dept. Geoquímica, Petrología i Prospecció Geològica, Universitat de Barcelona, C/ Martí i Franquès, s/n, \\ 08028, Barcelona, Spain. Email: galias@ub.edu \\ 3. ASOME (Departament de Prehistòria UAB) Mòdul de Recerca A, Campus de Bellaterra 08193, Barcelona, \\ Spain. Email:Ache: mireia_ache@hotmail.com \\ 4. CIPAG, C/ Onze de setembre, 32, 08859, Begues, Barcelona, Spain. Email: Fierro: eli.f.mila@gmail.com;
} Edo: cipagmedo@gmail.com

\begin{abstract}
:
Can Sadurní's cave, located in Begues (NE Iberian Peninsula), in the Baix Llobregat region, is an archaeological site with a wide stratigraphic sequence covering from the Epipaleolithic huntergatherers societies at the beginning of the Holocene to Roman times. During the excavations of the last years a large number of different raw materials used for the manufacture of axes have been recovered.

The present study is focused on the Neolithic sequence. 31 axes and adzes have been characterised petrographically with the aid of a binocular microscope and transmission microscope. A great variety of rocks constitute the raw materials of these stone tools, ranging from contact and regional metamorphic rocks to plutonic and porphyric igneous rocks. The formers are the most abundant (up to 78\%) and include hornfels, spotted phyllites, marbles, quartzites, slates and phyllites. The igneous rocks consist of granodiorite, porphyry and aplites. Such a great assemblage of rocks matches in a geological context representative of a plutonic intrusion and its metamorphic contact aureole. Following that scenario we suggest that the most likely source area for all these materials occur at the Collserola hills, at $27 \mathrm{~km}$ far to the east from the cave, at the other side of the Llobregat River, where an Hercynian granodiorite and related igneous rocks intruding Ordovician metasedimentary materials are presented.
\end{abstract}

Keywords: axe; Neolithic; archaeopetrology; Can Sadurní’s cave; lithic procurement

\section{Introduction}

The site of Can Sadurni covers a complete stratigraphy of the Holocene, consisting on 27 archaeological layers (Núñez et al. 2013). The aim of this study is to characterize the nature

Published by the School of History, Classics and Archaeology, University of Edinburgh ISSN: 2055-0472. URL: http://journals.ed.ac.uk/lithicstudies/

This work is licensed under a Creative Commons Attribution 2.5 UK: Scotland License. 
of the rocks used to manufacture the neolithic axes and adzes recovered in Can Sadurní's cave to define a first geological and geographical approach to its provenance. These results will help us to understand the potential degree of knowledge of the regional raw materials.

\subsection{Geological setting}

Can Sadurní's cave is located in the Garraf massif, $2 \mathrm{~km}$ northeast of the village of Begues (Barcelona, Spain). The site is situated in the north face of a hill parallel to the Begues rill at $421 \mathrm{~m}$ A.S.L., and it is considered a strategic natural interlock in the massif (Blasco et al. 1981).

The Garraf massif forms part of the Littoral Range within the Catalan Coastal Ranges, which extends over $250 \mathrm{~km}$ along the north-eastern coast of the Iberian Peninsula. The massif is a structure composed mainly of Jurassic and Cretaceous limestones and dolostones that lay unconformably the Triassic and Palaeozoic materials (Daura et al. 2014) (Figure 1). The cave occurs in the intensively karstified carbonate materials and it is part of the Begues polje (Montoriol 1964).

\subsection{Archaeological background}

In 1978 took place the first excavation of the site; until now, up to 37 archaeological campaigns have being carried out (Figure 2). The excavated surface is about $51 \mathrm{~m}^{2}$, in which 5 strata and 31 different layers have been identified. The oldest occupation of the site has been dated by ${ }^{14} \mathrm{C}$-AMS on $10540 \pm 60 \mathrm{BP}$. The sample -on bone- corresponds to the Ancient Epipalaeolithic layer "Microlaminar" (Fortea 1973).

The cave shows a long chronocultural sequence, characterized by several occupations from the Ancient Epipalaeolithic: "Microlaminar" facies and "Ancient geometric facies" as they were defined by Fortea (1973), Mesolithic ("Notches \& Denticulates" facies), Ancient Cardial Neolithic, ancient Epicardial Neolithic, Postcardial Neolithic, ancient Neolithic Chalcolithic, ancient and early Bronze Age and Iberian to Roman age (Edo et al. 2012).

\section{Methods and materials}

\subsection{Arqueopetrological method: laboratory analysis and fieldwork}

The characterization of the rocks is based on petrographical description at naked eye, with hand lenses and binocular magnifier. Only for two indistinguishable samples thin sections have been done for the study under transmission microscope. The state of conservation of the lithic assemblage is relatively good, and no chemical or mechanical postdepositional alterations are evident.

The petrographical study includes the identification of rock mineral assemblages and the diagnostic textures, in order to discriminate among igneous, sedimentary and metamorphic rocks. The macroscopic description follows the classical method based on the identification of the colour of the rocks, the percentage and kinds of minerals, the shape and the form of minerals, as well as, their orientation in the sample. 

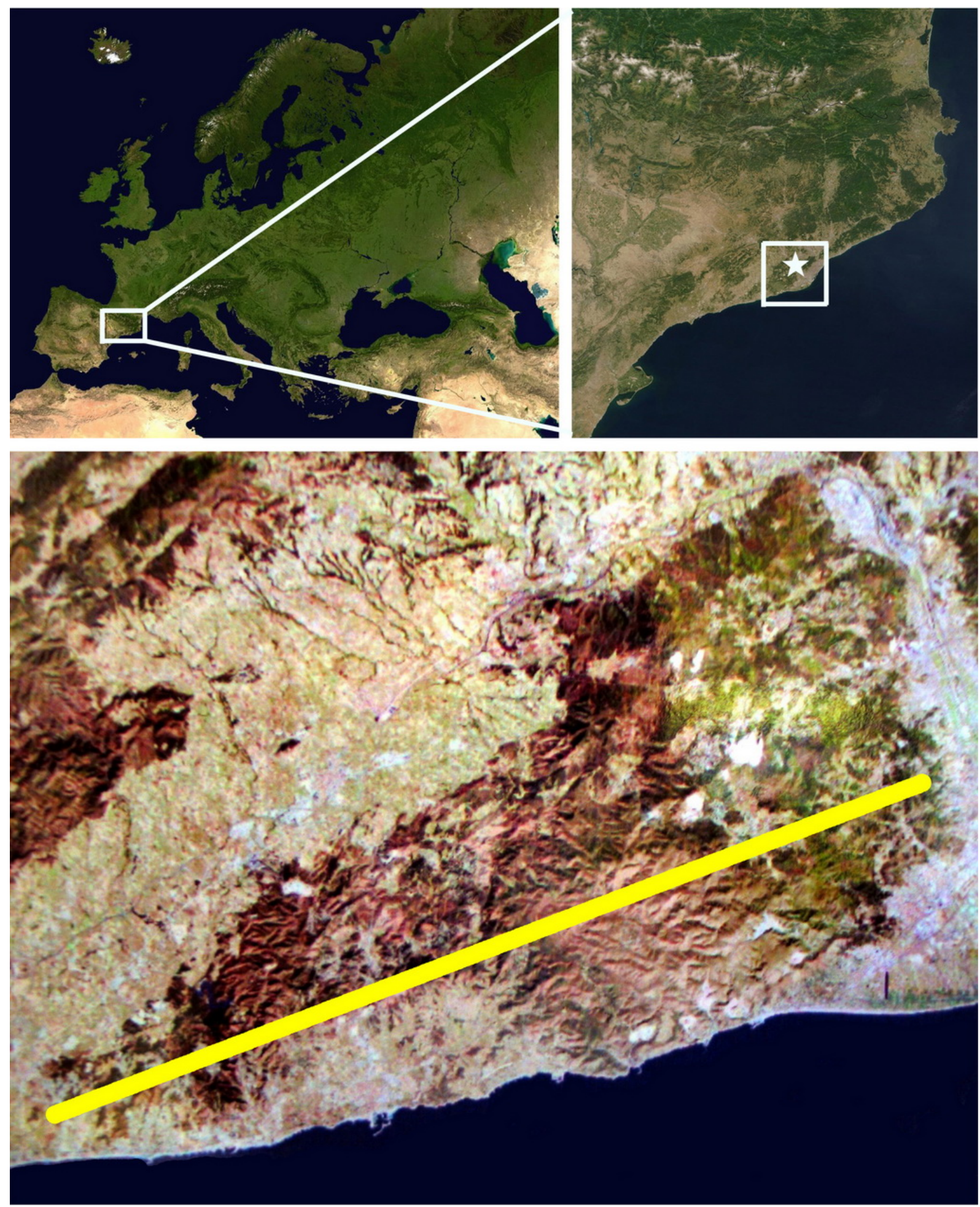

WSW

ENE

$1000 \mathrm{~m}$

BEGUES

$+500$

$+0$ $-500$

Figure 1. Location of Can Sadurní's cave and geological cross-section from Litoral range, in the Garraf massif (Gámez et al. 2011; ICGC 2016; NASA 2016). 


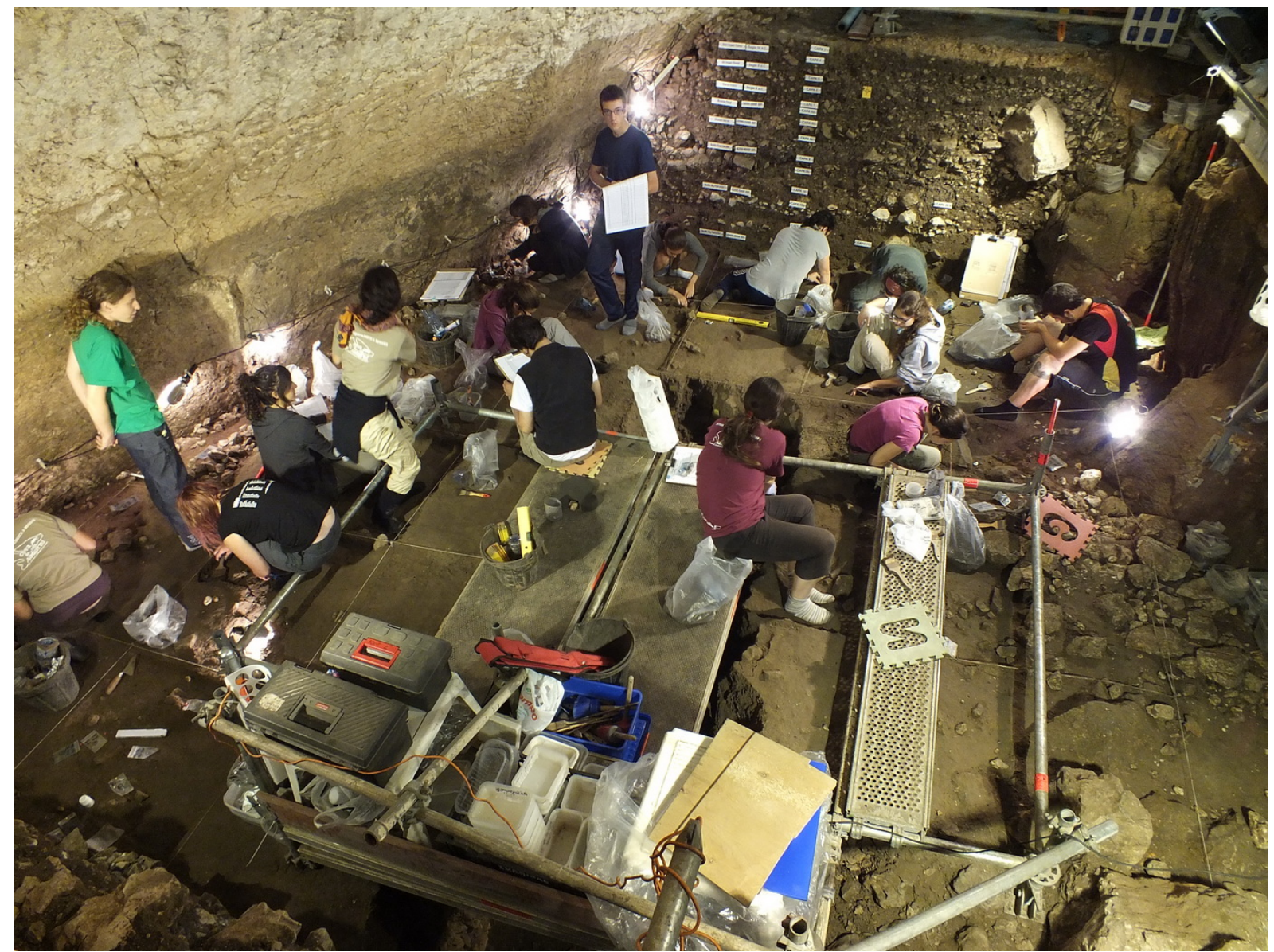

Figure 2. An ordinary working day at the cave in 2014.

Taking into account the different types of rocks available as raw materials, we used the geological maps -concerning this area- of the Geological Survey of Catalonia (Roca Adrover \& Miranda Canals 2010) at 1:25.000 and 1:10.000 scale; and the geological map -sheet number 420- of the Spanish Geological Services (IGME 2000) at 1:50.000 scale, in order to define several potential areas to survey and to sample. As a result, the fieldwork had been done in the Palaeozoic materials of the Garraf massif, and in other nearby areas, as Collserola range, in order to identify the most potential source-areas. The fieldwork in Collserola has shown several igneous and metamorphic rocks outcrops that have supplied different samples, which have been used to compare with the archaeological materials. These outcrops are located at the west of the town of Torrelles de Llobregat, where phyllites and quartzites are widespread represented and towards the south and the west of the hilltop of Sant Pere Màrtir, where Palaeozoic mottled hornfelses and porphyries are present. Besides, metamorphic and igneous pebbles were observed in the Quaternary terraces placed at Can Cortés and Can Biosca creeks.

\subsection{Macrolithic tools}

We analysed for this study a total number of 31 specimens (Figure 3). Twenty six of them show the presence of traces of manufacture, use, or both manufacture and use. The rest of specimens (five) have not been included in any functional group due to their small size, the lack of anthropogenic traces or its poor preservation (Figure 4).

The macrolithic tools of Can Sadurní appear highly fragmented and its degree of preservation is variable. Only six pieces (23\%) are unbroken. A half of the items (13: $50 \%)$ 
only preserves a third part of the original tool, and the rest of pieces (27\%) only two-thirds of the original item.

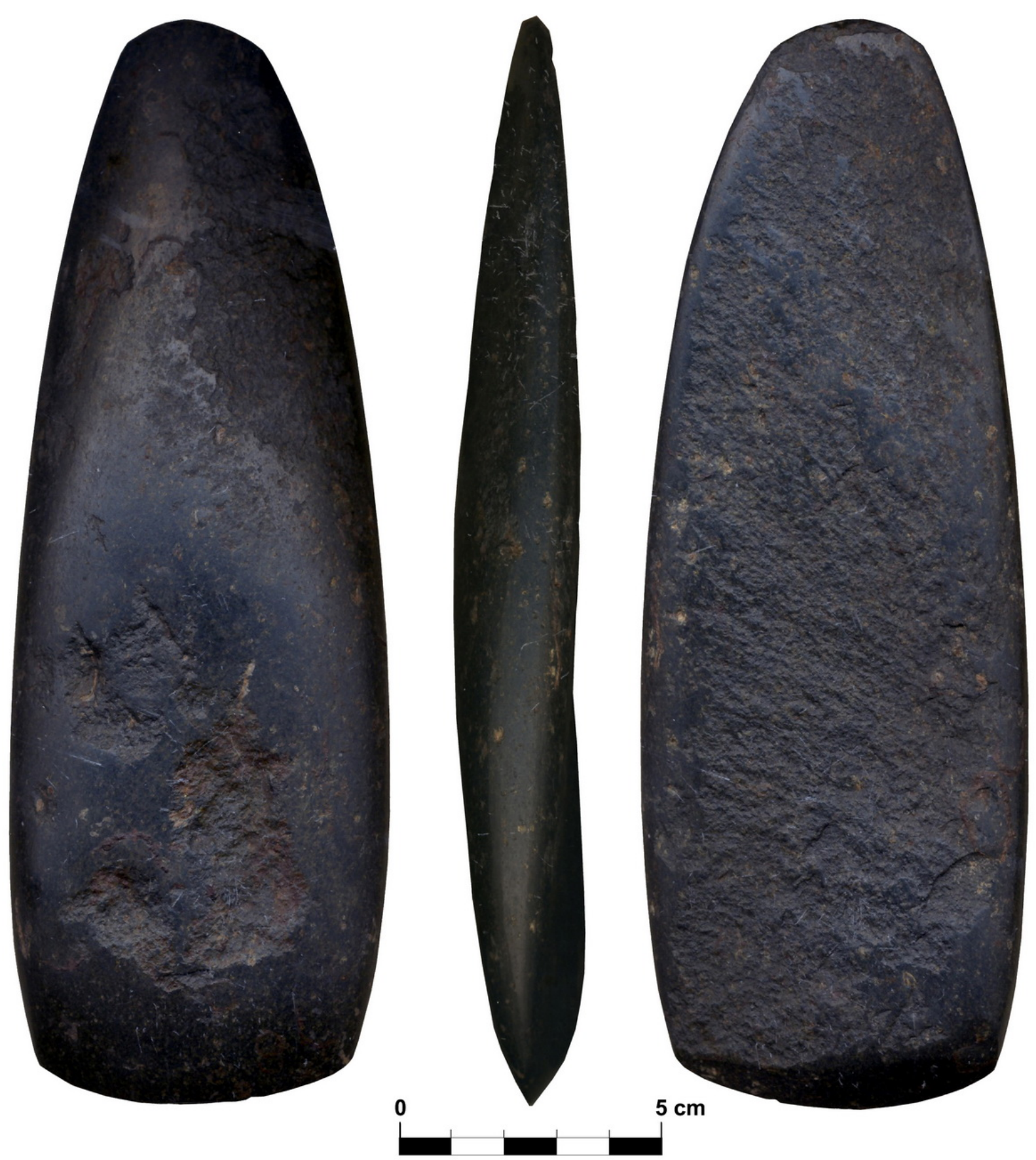

Figure 3. Neolithic adze (sample 08CS-KL12-EGr8-Spf-1) made from porphyry from 10b layer. The scale bar is $5 \mathrm{~cm}$ wide with $1 \mathrm{~cm}$ intervals.

The complete artefacts usually have broken or unutilized active surfaces so, along with fragmented items, they represents basically the waste of the production, typical of waste deposits or discards.

Taking into account the macroscopic and microscopic observation -at a range of magnification between $10 \mathrm{x}$ and $60 \mathrm{x}$ - of the preserved areas of the macrolithic tools, we have defined their typological classification considering its morphometric analysis based on the categories defined by Semenov (1981), Ricq of Bouard (1996), Bosch (1984) and Fíguls (2012). 


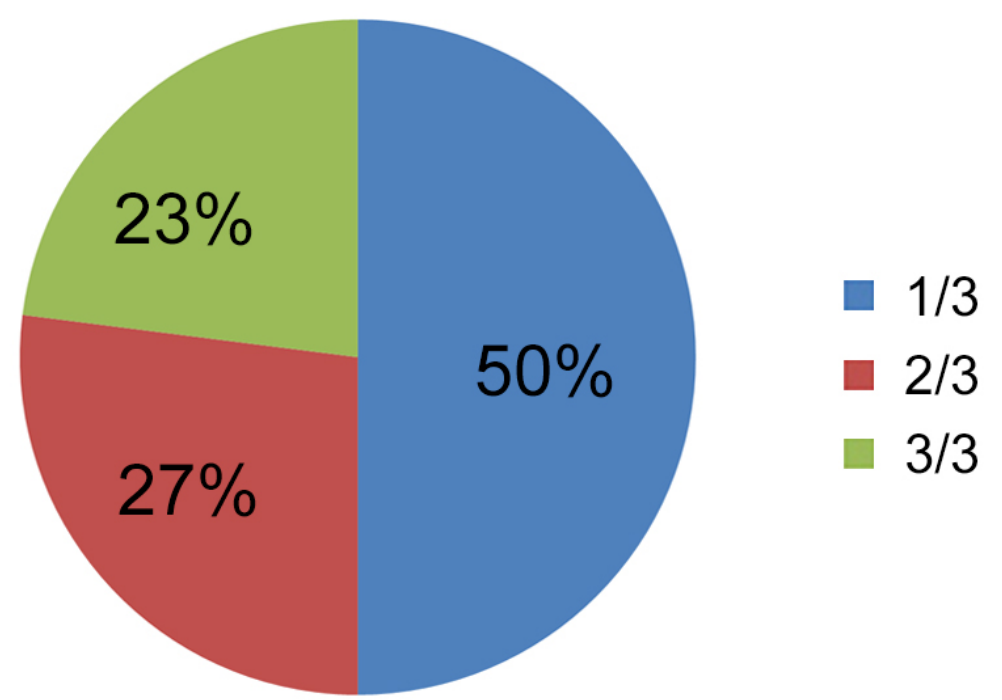

Figure 4. Degree of preservation of the macrolithic tools.

\subsubsection{Cutting edge tools}

A total number of ten cutting edge tools have been identified. Considering their profiles and setting, regarding its foot holder, they have been divided between five axes and five adzes. Moreover, we have five fragmented artefacts with the same morphology but without any active surface, so it has not been possible to define their tool category. We have also a flake potentially related with this kind of tools, and three cutting edge tools reused as hammers. All these tools, representing in fact the more abundant category of macrolithic tools (72\%) have been manufactured on metamorphic rocks, most hornfels and phyllites.

The scarcity of complete artefacts does not allow us to define morphometric or typological parameters, however their metric characteristics agree within the established parameters by authors in previous studies. These tools have suffered numerous modifications because of its manufacture and its use (Table 1).

Generally, the traces of manufacture involve uniformly pecking providing rough surfaces, which are necessary for foot holder. In some cases $(n=7)$, this pecking is combined with larger and aleatory removals allowing a greater anchorage or with a previous work of sleeking. The bevelled cutting edges of these artefacts have been intensively and carefully polished.

The use-wear traces observed in these artefacts correspond generally to very long stretch marks, commonly parallel. The direction of these stretch marks in relation to the edge allows us to determine the relative position of the handle and so, its typological category. Usually use-wear marks over the edge correspond to varying size fractures, according to the original worked material: small removals, which rarely exceed $5 \mathrm{~mm}$, resulting from soft materials, such as wood, and bigger removals due to the impact with harder materials, such as stones.

\subsubsection{Other tools}

The remaining specimens ( $n=7)$ show a high degree of fragmentation, that excludes their categorization as artefacts and do not allow us to precise properly any functional interpretation; six of them show use-wear traces and the other one could be a flake resulting from a percussive action. Small fronts of percussion in three of these artefacts and abrasion traces in the other three have been observed. 
Table 1. Use-wear traces and cutting edge percussor use from axes and adzes (based on Semenov, 1981; created by M. Ache). Abbreviations: OBL - oblique; PERP perpendicular.

\begin{tabular}{|c|c|c|c|c|c|c|c|c|c|c|c|c|}
\hline & \multirow[b]{2}{*}{ Label } & \multirow[b]{2}{*}{ Type } & \multirow[b]{2}{*}{ Preserved part } & \multicolumn{3}{|c|}{ Production traces } & \multirow[b]{2}{*}{ ڤั } & \multicolumn{2}{|c|}{ Edge morphology } & \multicolumn{3}{|c|}{ Use wear traces } \\
\hline & & & & 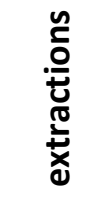 & 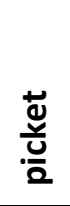 & 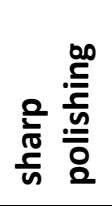 & & 㫣 & 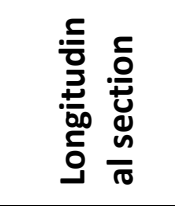 & 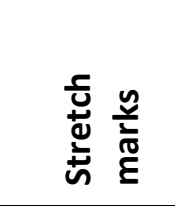 & $\frac{n}{2}$ & 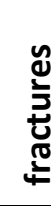 \\
\hline Layer & 02CS-E7-le-9-53 & axe percussor or adze & Top and middle part & & $x$ & $x$ & & & & & $x$ & $x$ \\
\hline \multirow[t]{3}{*}{9} & 03CS-E7-If-9-46 & axe & Top and middle part & $x$ & & $x$ & no & no & centred & $\mathrm{OBL}$ & $x$ & \\
\hline & 05CS-F11-IF-9-6 & axe percussor or adze & Complete & & $x$ & $x$ & & & & & $x$ & $x$ \\
\hline & 06CS-F11-Ie-9-37 & undefined axe or adze & Fragment & & $\mathrm{X}$ & $\mathrm{X}$ & & & & & & \\
\hline Layer & 07CS-D8-lg-9b-28 & undefined axe or adze & Fragment & & & $\mathrm{X}$ & & & & & & \\
\hline \multirow[t]{2}{*}{$9 b$} & 07CS-E6-Ig-9b-61 & adze & Top and middle part & $x$ & $\mathrm{X}$ & $x$ & yes & yes & displaced & PERP & $x$ & \\
\hline & 06CS-D10-Ig-9b-5 & axe & Complete & & $x$ & & no & no & centred & $\mathrm{OBL}$ & $X$ & \\
\hline Layer & 08CS-F6-lg-10-23 & axe (possibly) & Top part & $x$ & & $x$ & no & no & centred & $\mathrm{OBL}$ & $x$ & \\
\hline 10 & 08CS-L5-nq-10-28 & undefined axe or adze & Fragment & $x$ & & $x$ & & & & & & \\
\hline Layer & 09CS-E10-lg-10b-73 & axe & Complete & $x$ & $x$ & $x$ & & & centred & $\mathrm{OBL}$ & & $x$ \\
\hline \multirow[t]{2}{*}{$10 b$} & 08CS-KL12-EGr8-Spf-1 & adze & Complete & $\mathrm{X}$ & $\mathrm{X}$ & $\mathrm{X}$ & yes & yes & displaced & PERP & $x$ & \\
\hline & 09CS-E11-lg-10b-10 & adze(possibly) & Top and middle part & & $x$ & $x$ & yes & yes & centred & PERP & $x$ & $\mathrm{X}$ \\
\hline Layer & 03CS-G6-IIf-11-32 & undefined axe or adze & Middle part & & $\mathrm{X}$ & $X$ & & & & & & \\
\hline \multirow[t]{4}{*}{11} & 12CS-E6-lic-11-83 & axe percussor or adze & Complete & & $x$ & $x$ & & & & & $\mathrm{X}$ & $x$ \\
\hline & 12CS-E6-IIe-11-30 & undefined axe or adze & Middle and bottom part & & $x$ & $x$ & & & & & & \\
\hline & 96CS-I4-IIb-11-181 & axe & Right side & & $x$ & $x$ & & & centred & $\mathrm{OBL}$ & $x$ & \\
\hline & CS-H10-IIc-11-36 & adze & Complete & $x$ & & & yes & yes & displaced & PERP & $x$ & \\
\hline $\begin{array}{l}\text { Layer } \\
11 \mathrm{~b}\end{array}$ & $06 \mathrm{CS}-\mathrm{F} 10-1 \mathrm{~F}-11 \mathrm{~b}-3$ & adze & Fragment & & $x$ & & & & displaced & $\begin{array}{c}\text { PERP } \\
\text { (possibly) }\end{array}$ & $X$ & \\
\hline
\end{tabular}




\section{Results}

\subsection{Petrographic description}

The 31 axes and adzes studied in Can Sadurni's cave derive from a great diversity of rocks. A first approximation at naked eye allows us to subdivide into two groups of rocks, based on their colour. The darker ones represent the more abundant (75\%) and coincide with pelitic metamorphic rocks and porphyries, whereas the lighters represent plutonic rocks and a reduced number of metamorphic rocks.

Dark samples were mostly represented by contact metamorphic rocks (49\%), followed by foliated rocks (16\%), porphyry rocks (10\%) and one unidentified sample (Table 2) (Figure 5).
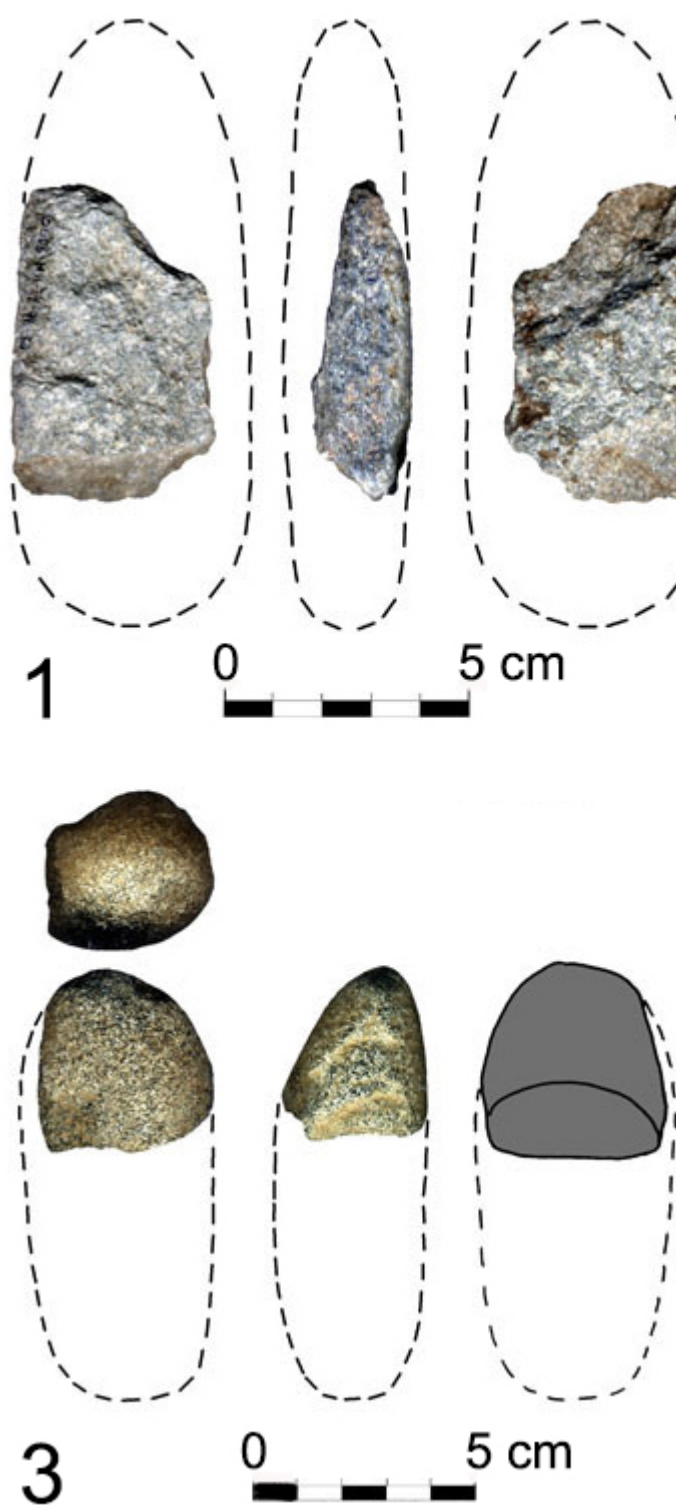

$5 \mathrm{~cm}$

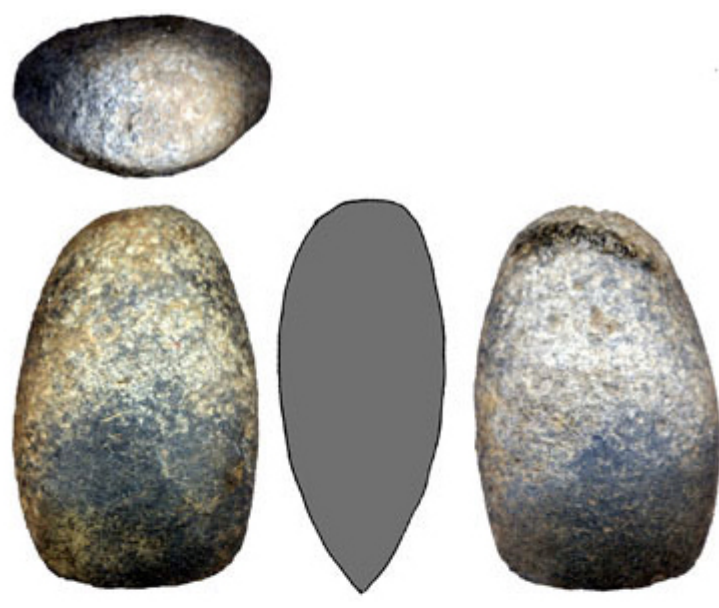

2
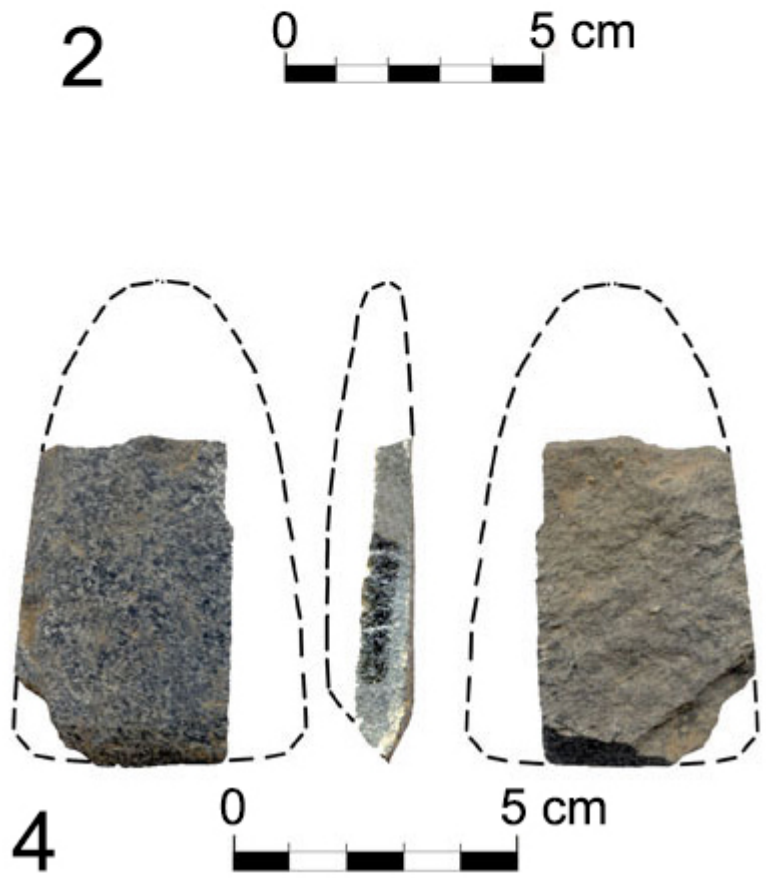

Figure 5. 1: sample 06CS-H11-If-9b-56 made from quartzite. 2: sample 06CS-D10-Ig-9b-5 made from mottled hornfels. 3: sample 10CS-D8-Ih-10b-11 made from transition phyllite-schist. 4: sample 06CS-F10-If-9b-3 made from slate. The scale bar is $5 \mathrm{~cm}$ wide with $1 \mathrm{~cm}$ intervals.

Contact metamorphic rocks include mottled and unmottled hornfels and mottled phyllites (Figure 6.), whereas foliated rocks consist of slates and phyllites representative of regional metamorphism. 
Table 2. List of rocks used as raw materials for axes industry. Abbreviations: C - colour; d - dark samples; l light samples.

\begin{tabular}{|c|c|c|c|c|c|}
\hline Nature of rocks & & Type of rocks & $\mathbf{C}$ & $\%$ & Total \\
\hline \multirow[t]{7}{*}{ Metamorphic } & \multirow[t]{2}{*}{ Contact metamorphism } & $\begin{array}{l}\text { Mottled, unmottled } \\
\text { hornfels, or both }\end{array}$ & $\mathrm{d}$ & 39 & \multirow[t]{7}{*}{25} \\
\hline & & Mottled phyllite & d & 10 & \\
\hline & \multirow{2}{*}{ Regional metamorphism } & Phyllite & d & 10 & \\
\hline & & Slate & $\mathrm{d}$ & 6 & \\
\hline & \multirow{3}{*}{$\begin{array}{l}\text { Contact, regional } \\
\text { metamorphism, or both }\end{array}$} & Quartzite & l & 10 & \\
\hline & & Marble & 1 & 3 & \\
\hline & & Unknown & $\mathrm{d}$ & 3 & \\
\hline \multirow[t]{4}{*}{ Igneous } & Plutonic & Granodiorite & l & 3 & \multirow[t]{4}{*}{6} \\
\hline & & Aplite-pegmatite & 1 & 3 & \\
\hline & Hypabissal & Porphyry & d & 10 & \\
\hline & & Unknown & l & 3 & \\
\hline
\end{tabular}
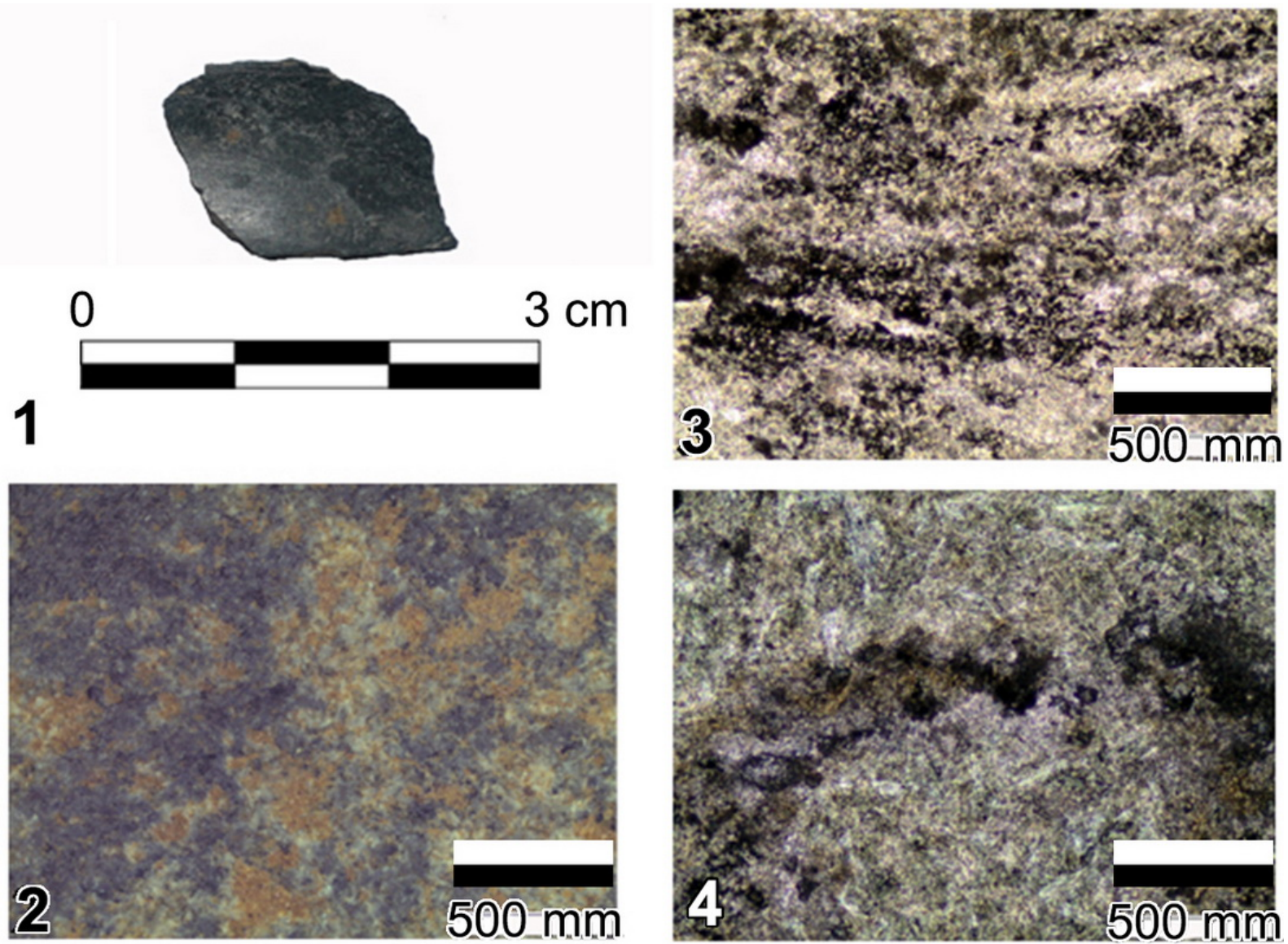

Figure 6. Dark axe (fragment) sample 96CS-I4-IIb-11-181. Mottled phyllite. 1) Hand sample The scale bar is 3 $\mathrm{cm}$ wide with $1 \mathrm{~cm}$ intervals; 2) Spotted texture (binocular magnifier: scale $500 \mathrm{~mm}$ ); 3) Fine-grained granoblastic matrix (optical microscope: scale $500 \mathrm{~mm}$ ) and 4) Cordierite porphyroblast replaced by chlorite and muscovite surrounded by a fine-grained matrix (optical microscope: scale $500 \mathrm{~mm}$ )..

Light samples comprise granodiorites, aplite-pegmatites, one unidentified sample and, as metamorphic rocks, quartzites and marbles (Figure 7).

Micropetrographic observations allow more detailed characterization of the texture and the mineral assemblage of each singular rock. 

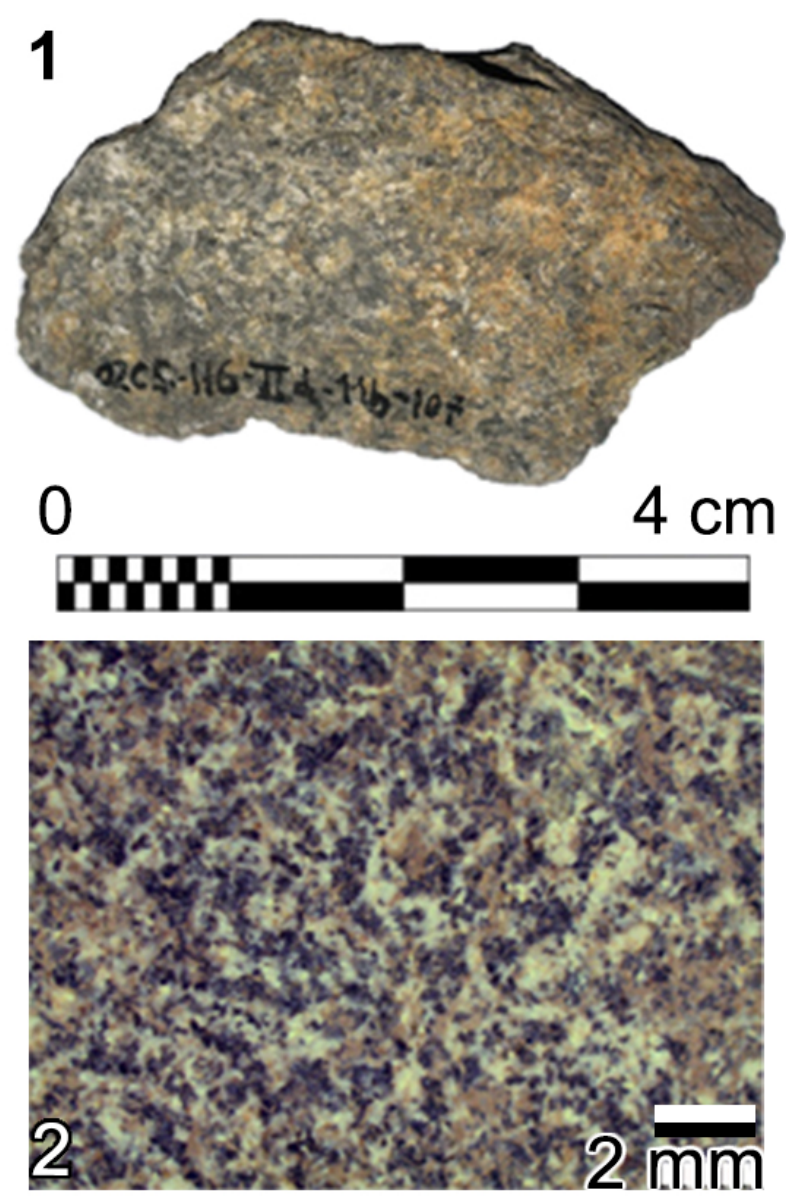

Figure 7. Light axe (fragment) sample 02CS- H6-IId-11b-107. Granodiorite. 1) Hand sample.The scale bar is 4 cm wide with $1 \mathrm{~cm}$ intervals.; 2) Granular texture (binocular magnifier: scale 200mm).

Hornfels are isotropic in appearance with small porphyroblasts (ranged in 1 to $2 \mathrm{~mm}$ in size) included in a fine-grained matrix. Porphyroblasts are mainly cordierites (see Figure 6) which form rounded to oblate crystals of black to purple colour; however in some samples decussated prismatic white crystals of quiastolite may be also present. Matrix usually is retrogressed to sericite and consists of decussate muscovite and biotite, granoblastic quartz and accessory minerals such as titanite and iron oxides. Spotted phyllites share the same mineral assemblage though foliation is the outstanding character, along with the aphanitic and shiny appearance. Some rocks can be considered strictly the transition between hornfelses and spotted phyllites as they present both foliated and decussated textures. Slates and phyllites are aphanitic with greyish dark colours and show a pervasive foliation formed by phyllosilicates. Marbles are white colour rocks with granoblastic texture, composed of calcite crystals of 2 $\mathrm{mm}$ in size. Quartzites are finer grained, harder and consist mainly of quartz.

Porphyry has an inequigranular texture made of idiomorphic phenocrysts of quartz embedded in an aphanitic dark matrix. Phenocrysts are $2 \mathrm{~mm}$ in size and are scarce (up to 5\% in volume) but stand up by its white colour. Granodiorite is a coarse-grained rock with an equigranular texture formed by crystals of quartz and feldspars of $2 \mathrm{~mm}$ in size, and minor amounts of biotite and muscovite. Aplite is recognized by the homogeneous mosaic of small grains (up to $1 \mathrm{~mm}$ in diameter) consisting uniquely of quartz and feldspar.

The overall assemblage of rocks recognised in Can Sadurní's cave is distinctive of a geological context where extensive thermal aureole develops around plutonic intrusion and its related dyke swarm. In particular, the contact aureole is superimposed on low-grade regional metamorphism as the presence of spotted phyllites indicates. In fact, the occurrence of both 
hornfelses and spotted phyllites suggest the existence of two zones representing different metamorphic grades (the internal and the external aureole) related to the metamorphic gradient between the intruding magma and the surrounding country rock (Figure 8).
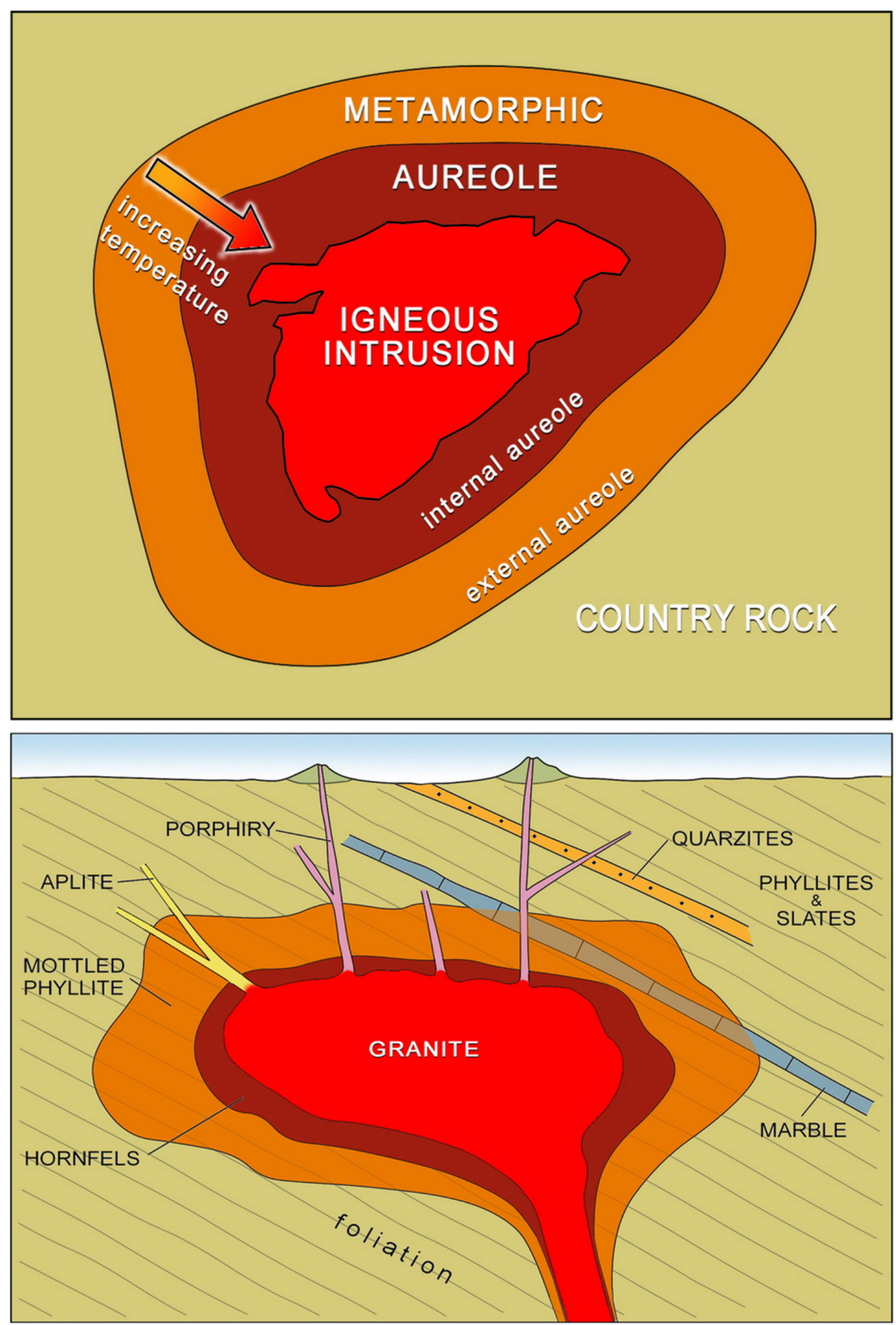

Figure 8. Schematic illustration of an igneous intrusion and its contact metamorphic aureole distinguished from the country rock. A) Plant view of metamorphic zones’ distribution inside the aureole. B) Cross-section view and localization of major rocks. 


\subsection{Fieldwork}

A fieldwork has been done in order to know the most possible source area for the supplying lithic materials similar to the archaeological samples. Two sectors have been taken into account: the sector at the vicinity of the cave in Begues, and the sector located at the other side of the Llobregat River, the Collserola range.

Sant Sadurni's cave is located in the Cretaceous limestones and very close to the Jurassic dolostones and Triassic carbonate materials. None of these rocks coincide with our samples. Further to the east, the Buntsandstein conglomerates contain a great variety of clasts, though the majority are made of quartz. Even more to the east, at the locality of Torrelles del Llobregat, metamorphic Palaeozoic rocks, such as phyllites and quarzites, occupy a large extension, though locally they are covered by alluvial deposits (e.g., La Clota and Torrelletes creeks) consisting of silts, sands and gravels. The gravels present very little clasts (range between $2-5 \mathrm{~cm}$ ) of mottled hornfelses, unmottled hornfelses, phyllites and mottled phyllites.

In the Collserola range at the surroundings of the Barcelona granodiorite outcrop contact metamorphic rocks four outcrops have been studied: in the n. 1 (Finestrelles), at the west of Sant Pere Màrtir hilltop, mottled and unmottled hornfelses occur. Further to the south, a porphyry dyke (outcrop n. 2) and phyllites and mottled hornfelses (outcrop n. 3) have been found. And, finally, at Can Cortés and Can Biosca creeks (outcrop n.4), local Quaternary terraces formed by sands and gravels with metamorphic and igneous pebbles up to $6 \mathrm{~cm}$ length are present (Figure 9).

\section{Discussion and conclusions}

\subsection{Discussion}

The analysis of the archaeological record of the Neolithic axes of Can Sadurní cave show that the overall rock assemblage fits perfectly in a geological context typical of regional metamorphic environment, accompanied by igneous intrusions and the surrounding metamorphic aureoles. However, considering the outcrop materials of the Garraf massif is difficult to consider this region as the supply area. The Garraf massif is composed mainly of limestones and dolostones of Jurassic and Cretaceous age and uniquely to the east, parallel to the Llobregat River, Triassic materials and the Palaeozoic basement are present. The Palaeozoic basement is represented by Ordovician - Cambroordovian and Silurian rocks affected by Hercynian low-grade regional metamorphism. Therefore a monotonous sequence of quartzites and phyllites predominates in this area, with no signals of contact metamorphism and granitic intrusions. However the pebbles of the Quaternary terraces in the vicinity of Can Sadurni cave contain igneous or contact metamorphic rocks of small dimensions. At the other side of Llobregat River, just at northwest of Barcelona city, the Collserola range exhibits the overall rock assemblage. In this area, a fairly complete Palaeozoic stratigraphic sequence (from Cambro-Ordovician to Carboniferous) crops out, although the oldest rocks occupy the most of the part. The whole sequence has been affected by polyphase deformation accompanied by a regional low-grade metamorphism during the Hercynian orogeny. LateHercynian granodiorite and a swarm of pegmatites, aplites and porphyry dykes intrude the Palaeozoic sequence resulting in a contact aureole of up to a $1 \mathrm{~km}$ width (Gil Ibarguchi \& Julivert 1988; Alías et al. 2008; Vila \& Pin 2015).

Most of the rocks are slates, phyllites, quarzites, marbles and metabasites formed during regional metamorphism, but spotted hornfelses and phyllites are also present within the contact aureole, at the vicinity of the Barcelona granodiorite. Aureoles adjacent to felsic intrusions (e.g., granodiorites) are usually restricted to relatively shallow depths and range from about 0.5 to $2.5 \mathrm{~km}$ in width. 

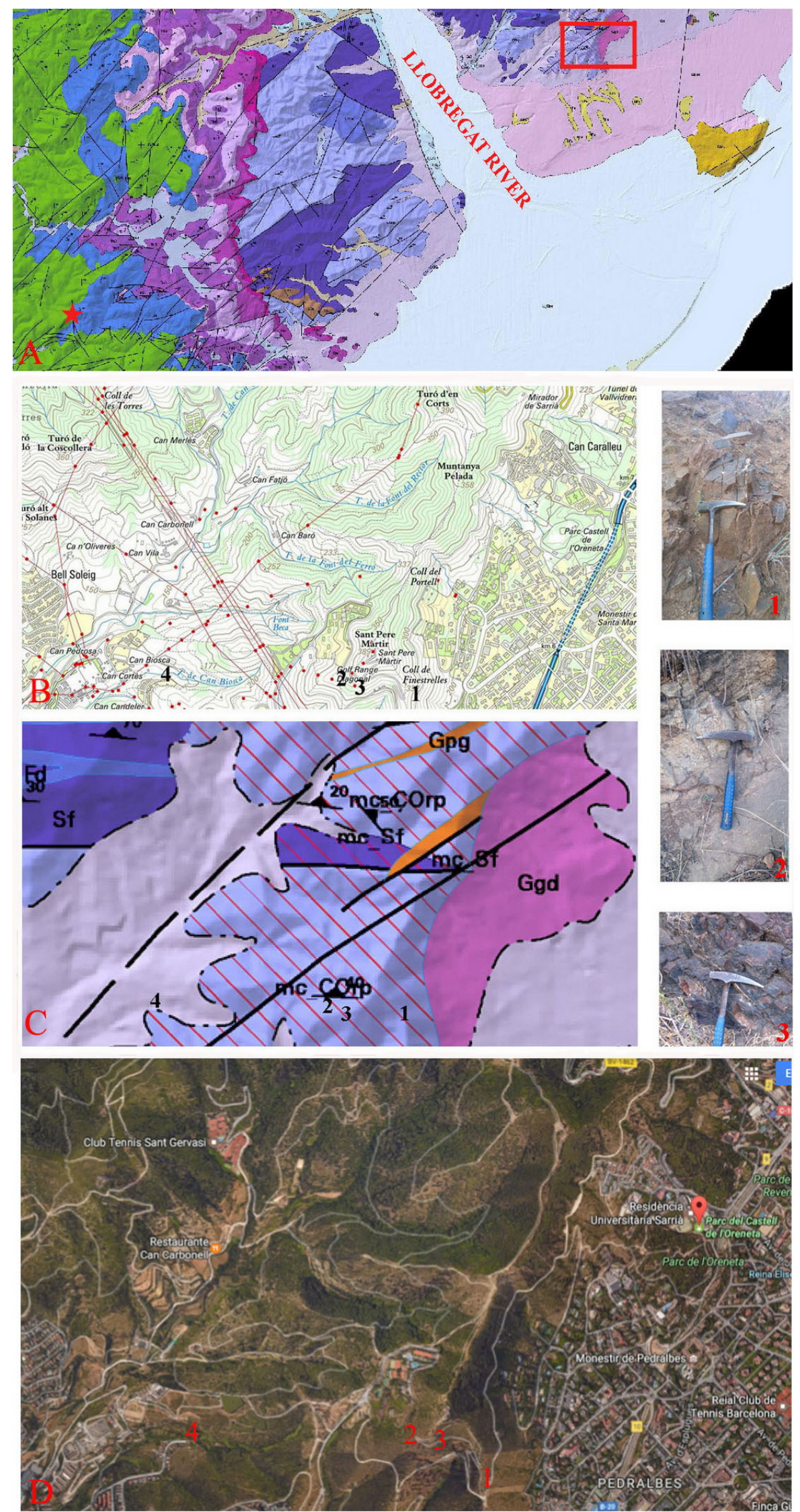

Figure 9. A: General map of Collserola range (1:25.000). Star: Can Sadurní's cave. B: Road map (1:10.000). C: Geologic map (1:10.000). D: Google Earth view. Geological points and images from geological surveys’ . n.1: Finestrelles; 2: Sant Pere Màrtir hilltop; 3: Sant Pere Màrtir hilltop; 4: Can Biosca creek. Sources: ICGC (2016), Google Maps (2016). 
The raw materials described in this study coincide completely with those occurring at the Collserola range (Figure 10), and more specifically with those related to the igneous intrusion and the surrounding rocks close to the Sant Pere Màrtir hilltop. Even two different kinds of hornfelses can be equivalent to those derived from the metamorphism of Cambro-Ordovician pelites (gray dark colour with porphyroblasts of cordierite) and the metamorphism of Silurian graphitic-rich pelites (black colour with porphyroblasts of andalusite). Uniquely, the metabasites have not been found as a raw material, probably because they are distant from the supply area.
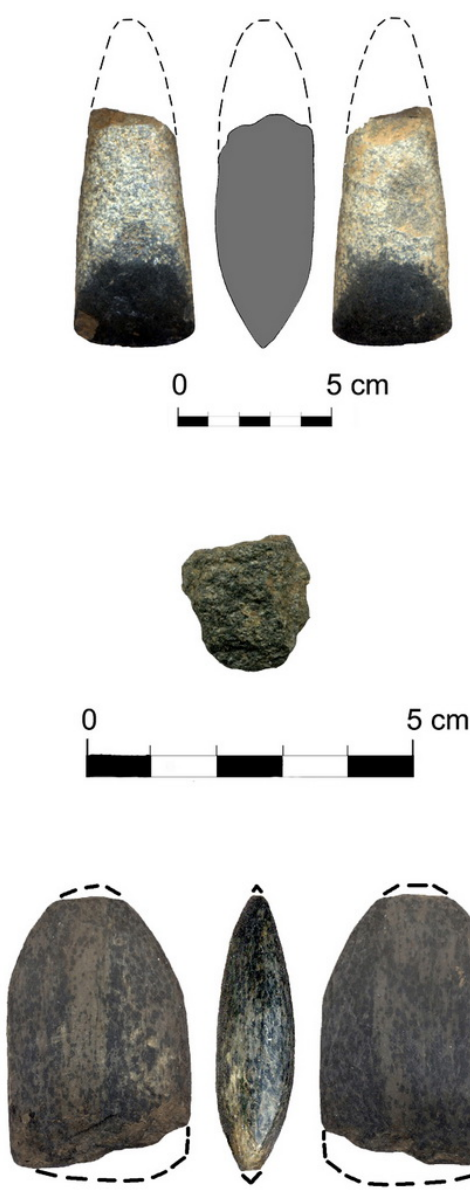

0
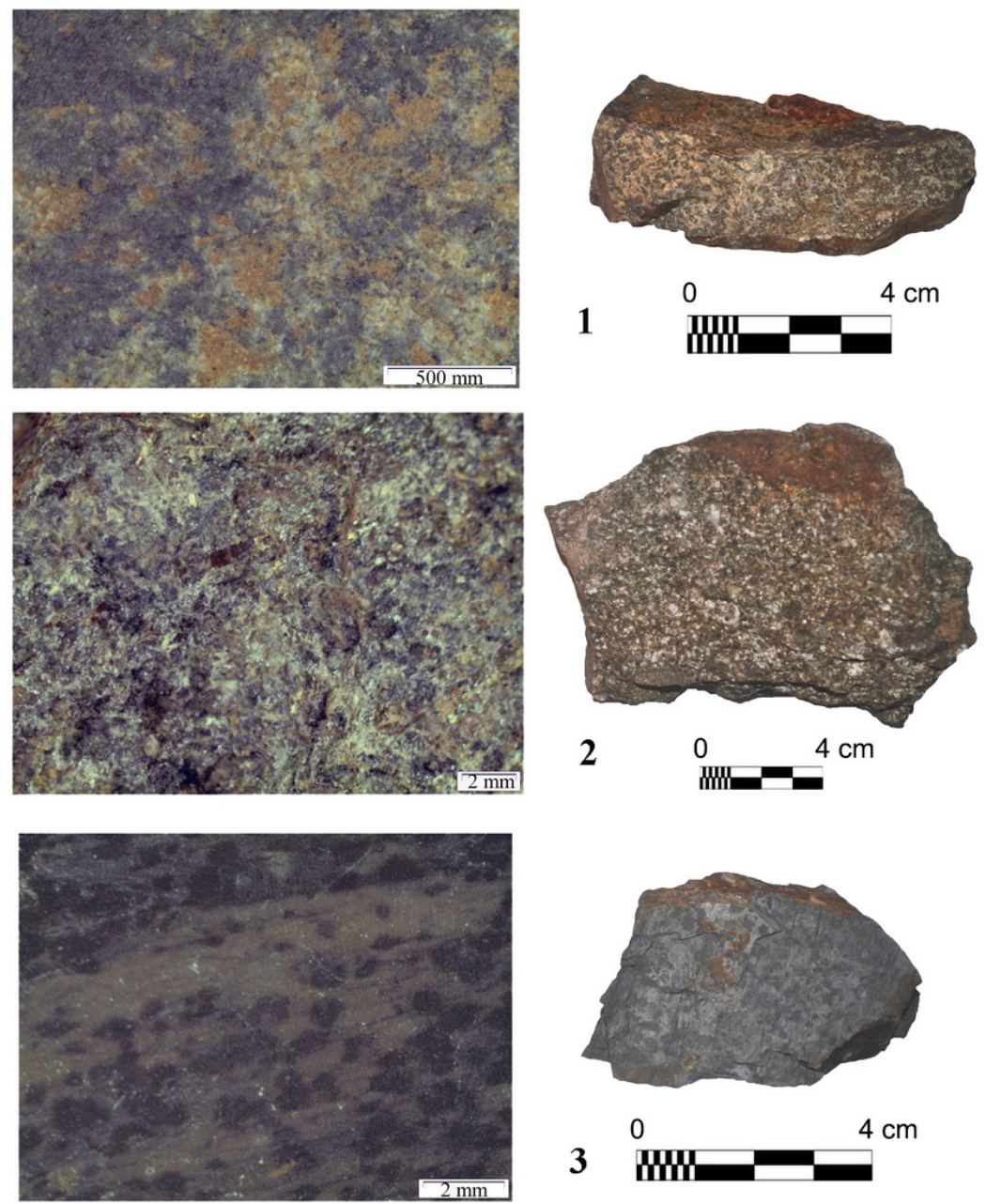

Figure 10. Archaeopetrological comparison between texture and mineralogy from the axes and the geological samples collected at different outcrops. From top to bottom: Axe made of mottled hornfels (sample 07CS-E6Ig-9b-61) and its geological correspondance sample (binocular magnifier: scale $500 \mathrm{~mm}$ ), fragment of axe made of porhyry (sample 11CS-D9-Ih-10b-221) and its geological correspondance sample (binocular magnifier: scale $2 \mathrm{~mm}$ ) and axe made of mottled phyllite (sample 09CS-E10-Ig-10b-73) and its correspondance sample (binocular magnifier: scale $2 \mathrm{~mm}$ ). The scale bar is 4 or $5 \mathrm{~cm}$ wide with $1 \mathrm{~cm}$ intervals.

Regarding the geological map of the Collserola range close to Llobregat River, such a diversity of rocks is exposed in an area of about $8 \mathrm{~km}^{2}$ (see Figure 9). We consider that the most plausible hypothesis is that the inhabitants of the cave found all the materials concentrated in a single outcrop as an alluvial deposit (see other authors like Fíguls 2012). The first explorations done at Can Cortés and Can Biosca creeks close to Sant Pere Màrtir hilltop have shown that metamorphic and igneous pebbles are very small to explain the supplied material, so more explorations in others creeks should have to be realized. We have 
to keep in mind the great human impact of the whole area that, probably, will hinder our future research strategy.

\subsection{Conclusions}

Macroscopic and microscopical study of a total of 31 Neolithic axes from the site of Can Sadurní, let us to discriminate two different groups, the light axes and the dark axes, corresponding to igneous and metamorphic rocks respectively.

The great spectra of metamorphic and igneous rocks let us to conclude that all the rocks fit perfectly in a geological context of a metamorphic aureole developed around an igneous intrusion (Figure 11).

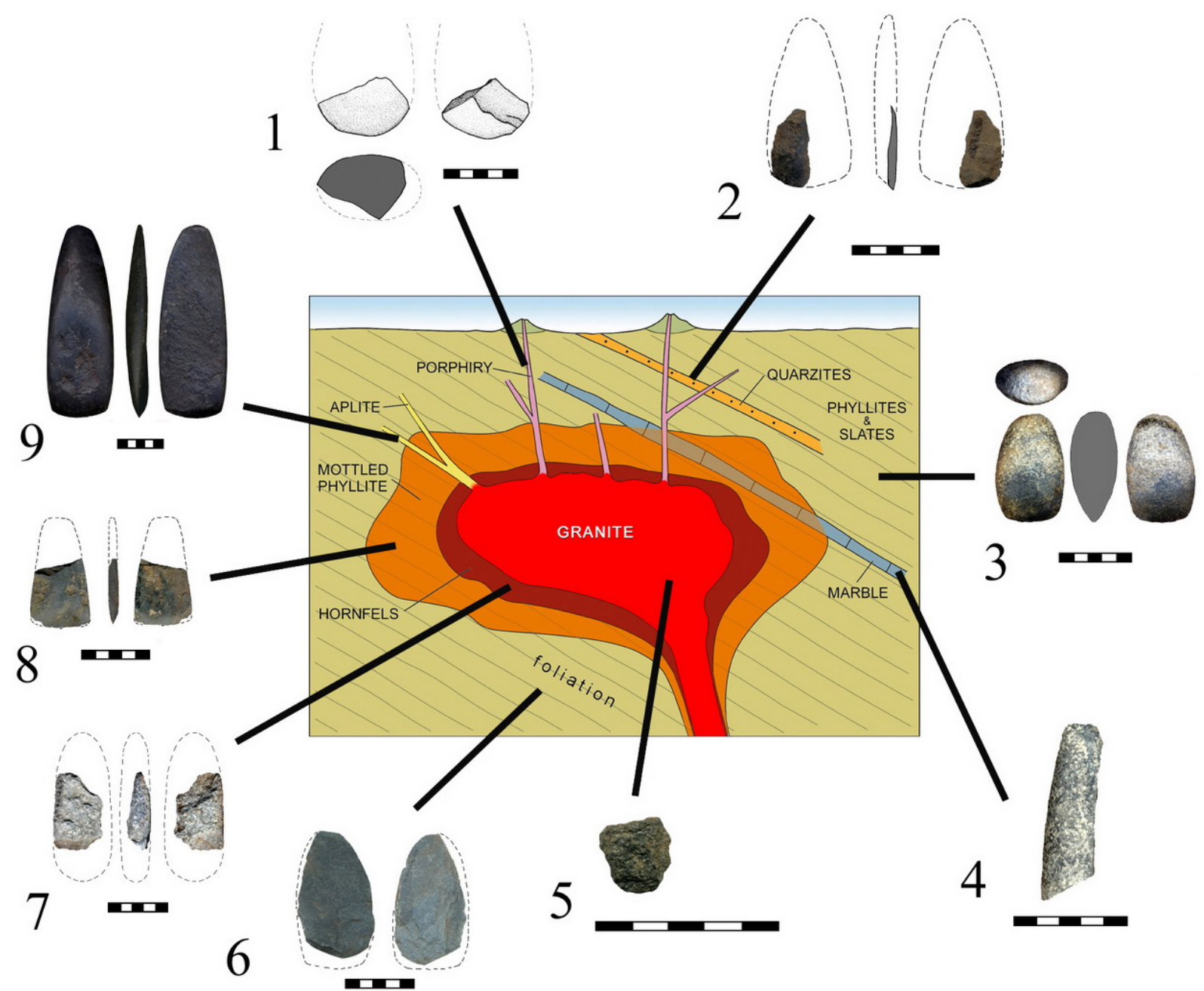

Figure 11. Localization of raw materials in relation to the schematic distribution of contact metamorphic rocks and plutonic intrusion. 1: sample 03CS-I9-IId-11-29. 2: sample 06CS-H11-If-9b-56. 3: sample 06CS-D10-Ig-9b5. 4: sample CS-G-32. 5: sample 11CS-D9-Ih-10b-221. 6: sample 03CS-I8-IIIc-18-51. 7: sample 06CS-H11-If9b-56. 8: sample 08CS-LB12-Spf-252. 9: sample 08CS-KL12-EGr8-Spf-1. The scale bars are $5 \mathrm{~cm}$ wide with 1 cm intervals.

This geological context can be found at a distance of $27 \mathrm{~km}$ as the crow flies, from Can Sadurni's cave, crossing the Llobregat River, at Collserola range, particularly at Sant Pere Màrtir hilltop.

So, we can suggest Collserola range as the closer and most likely area of original provenance of the raw materials used to manufacture the axes and adzes at Can Sadurní, but we also suggest that raw material procurement have been collected probably in secondary 
outcrops, like the Llobregat River terraces, that nowadays kept yet unknown due to the high disturbance of that area, near the city of Barcelona. This would mean a well-known mobility pattern by the inhabitants of the cave, reaching medium distances to collect raw materials from the terraces as secondary outcrops, were raw material could be found easily and probably in a good shape and size.

From a Neolithic mobility pattern studies point of view, similar works concerning this subject of the macrolithic tools procurement in the north-eastern Iberia in general or in this area - near the Llobregat River mouth - have been done by different authors (Álvarez 1993; Risch 1995; Risch \& Martínez Fernández 2008; Fíguls et al. 2012); assuming that the exact determination of the original procurement area of the Neolithic axes is unfeasible from a strictly petrographic perspective, a few of them discard the Collserola range and that area of the Llobregat River as a provenance zone of raw materials for polished stone tools during the Neolithic; basically considering, on one hand, the inexistence of prehistoric quarries, and on the other hand, taking into account morphological criteria of the original lithic supports. In fact, it is well known that there is a long tradition of discoveries of prehistoric macrolithic tools along the Segre River, with many workshops detected (Maluquer de Motes 1979; Risch 1995; Risch \& Martínez Fernández 2008). Nevertheless, other authors (Fíguls et al. 2012) positively suggested that this zone of Collserola range might have also to be considered as a potential area of supply.

Nowadays, many areas of the Collserola range are intensively disturbed, which could hamper the location of prehistoric quarries or workshops, nevertheless an integral research of polished stone tools workshops along the Llobregat River in that area and specifically on their terraces, has not been done.

\section{Acknowledgements}

The research described in this paper has been sponsored by several projects: HAR201455131 project (Ministerio de Economía y Competitividad); Les comunitats prehistòriques del massís del Garraf nord. Orígens, genètica, patrons d'assentament, trets culturals, recursos i mobilitat durant la Prehistòria recent. Reformulación del proyecto 2005-2012: La Prehistòria al sud-est del Llobregat. De la costa al massís Garraf-Ordal (Generalitat de Catalunya, Departaments de Cultura, Joventut i Ensenyament. Ajuntaments de Begues, Vallirana i Subirats, Universitat de Barcelona (Departament de Prehistòria), Universitat Politècnica de Catalunya (Escola Politècnica Superior d’Edificació de Barcelona), Cardiff University, Centre d'Estudis Beguetans, Instituto de la Cerveza Artesana) and SRG2014-108 project (AGAUR, Generalitat de Catalunya) and (SGR) GEOPAM ref. 2014SGR869. The authors also like to thank Pep Agulló for the drawings.

\section{References}

Ache, M. 2011, Els artefactes macrolítics del nivells neolítics de la Cova de Can Sadurní. In: Jornades internacionals de Prehistòria "30 anys d’investigació arqueológica al Garraf”, Begues, December of 2008 (Blasco, A., Edo, M. \& Villalba, M.J., Eds.), Edar Hugony, Milan: p. 129-140. (in Catalan) ("Macrolithic artefacts from neolithic levels of Can Sadurní's cave”)

Alías, G., Aulinas, M. \& Tubau, X. 2008, Petrological and geochemical characterization of metabasites from Collserola range (Barcelona). In: VIII Congreso geológico de España, 14-18 July, Las Palmas de Gran Canaria (Fernández, L.P., Fernández, A., Cuesta, A. \& Bahamonde, J.R., Eds.), Geotemas Vol. 10, Sociedad Geologica de España, Oviedo: p. 821-824. 
Álvarez, A. 1993, Tipologia petrogràfica en les destrals polides a Catalunya. Empúries, 4850(1): 18-25. (in Catalan) ("Petrographic typology of polished axes from Catalonia”) URL: http://www.raco.cat/index.php/Empuries/article/view/118235

Blasco, A., Blanch, M., Edo, M. \& Millan, M. 1982, La cova de Can Sadurní, una cruïlla de camins. Pyrenae, 17-18(1981-1982): 11-34. (in Catalan) (“Can Sadurní's cave, a crossroad”) URL: http://www.raco.cat/index.php/Pyrenae/article/view/164993

Blasco, A., Edo, M. \& Villalba, M.J. 2006, Evidencias de procesado y consumo de cerveza en la Cueva de Can Sadurní (Begues, Barcelona) durante la Prehistoria. In: IV Congreso Neolítico Peninsular, Vol. 1 (Hernández Pérez, M.S., Soler Díaz, J.A. \& López Padilla, J.A., Eds.), Museo Arqueológico de Alicante (MARQ), Alicante: p. 428-431. (in Spanish) ("Evidence of processing and human consumption of beer in Can Sadurnís cave (Begues, Barcelona) during Prehistory")

URL: https://dialnet.unirioja.es/servlet/articulo?codigo=2865599

Bosch, A. 1984, Les destrals polides del nord de Catalunya: Tipologia i petrologia. Fonaments. Prehistòria i Món Antic als Països Catalans, 4: 221-245. (in Catalan) ("Polished axes from north Catalonia: typology and petrology")

Daura, J., Sanz, M., Fornós, J.J., Asensio, A. \& Julià, R. 2014, Karst evolution of the Garraf massif (Barcelona, Spain): Doline formation, chronology and archaeo-palaeontological archives. Journal of Cave and Karst Studies, 76(2): 69-87. doi:10.4311/2011ES0254

Edo, M. \& Alonso, M. 1982, Can Sadurní, Begues. In: Les excavacions arqueológiques a Catalunya en els darrers anys (Servei d'Arqueologia, Ed.), Excavacions Arqueològiques a Catalunya Vol. 1, Departament de Cultura de la Generalitat de Catalunya, Barcelona: p. 65-67. (in Catalan) (“Can Sadurní, Begues”)

Edo, M., Antolín, F. \& Barrio, M.J. 2012, Can Sadurní (Begues, Baix Llobregat), de la captación de recursos abióticos al inicio de la minería de aluminofosfatos (10500-4000 CAL ANE) en el macizo del Garraf. Rubricatum, Revista del Museu de Gavà, 5(Actas del Congreso Internacional Xarxes al Neolític): 299-306. (in Catalan) (“Can Sadurní Begues, Baix Llobregat- from abiotic ressources captation to aluminumphosphats mining (10,500-4,000 Cal. BCE) in Garraf Massif”) URL: http://www.raco.cat/index.php/Rubricatum/article/view/269765

Edo, M., Blasco, A. \& Villalba, M.J. 2011a, La cova de Can Sadurní, guió sintètic de la prehistòria recent al Garraf. In: Jornades internacionals de Prehistòria "30 anys d'investigació arqueológica al Garraf”, Begues, desembre de 2008 (Blasco, A., Edo, M. \& Villalba, M.J., Eds.), Edar Hugony, Milan: p. 13-96. (in Catalan) (“Can Sadurní's cave, synthetic script of recent Prehistory in Garraf”)

Fíguls, A., Grandia, F. \& Weller, O. 2012, Assaig sobre la xarxa d'intercanvis de recursos naturals, béns semielaborats i béns acabats en roques metamòrfiques i ígnies al "Solsonià”. Rubricatum, Revista del Museu de Gavà, 5(Actas del Congreso Internacional Xarxes al Neolític): 223-231. (in Catalan) ("Network exchange essay about natural ressources, semi-finished and finished goods in metamorphic and igneous rocks in 'Solsonià'”)

URL: http://www.raco.cat/index.php/Rubricatum/article/view/269689

Gámez, D., Angelet, C., Torrades, P. \& Llorens, F. 2011, Evolució de la línea de costa del Delta del Llobregat durant l'Holocè (Epipaleolític-actualitat). In: Jornades Internacionals de Prehistòria "30 Anys d'Investigació Arqueològica a Garraf”. Begues, desembre 2008 (Blasco, A., Edo, M. \& Villalba, M.J., Eds.), Edar Hugony, 
Milan: p. 187-191. (in Catalan) (“Coast range evolution of Llobregat's delta during Holocene (Epipalaeolithic - today)”)

Gil Ibarguchi, J.I. \& Julivert, M. 1988, Petrología de la aureola metamórfica de la granodiorita de Barcelona en la Sierra de Collserola. Estudios Geologicos, 44(5-6): 353374. (in Spanish) ("Petrology of granodiorite's metamorphic aureole in Collserola range, Barcelona”) doi:10.3989/egeol.88445-6552

Google Maps 2016, Google Maps. Google. Retrieved 06 August 2016.

URL: https://www.google.es/maps/

Institut Cartogràfic i Geològic de Catalunya (ICGC) 2016, VISSIR V3.26 (Computer software). Institut Cartogràfic i Geològic de Catalunya. Retrieved 03 February 2016. URL: http://www.icc.cat/vissir3/

Instituto Geológico y Minero de España (IGME) 2000, Mapa Geológico de España, Escala 1:50000, Serie MAGNA, Segunda serie, Madrid, Hoja 420. Instituto Geológico y Minero de España, Madrid. (in Spanish) (“Geological map of Spain”)

Maluquer de Motes, J. 1979, Notes de Prehistòria catalana: Una indústria lítica de la comarca de la Noguera. Pyreane, 15-16: 251-267. (in Catalan) ("Notes on Catalan prehistory: A lithic industry of La Noguera county”)

Montoriol, J. 1964, Estudio de las formas kársticas hipogeas desarrolladas en los bordes del poljé de Begas (Macizo del Garraf, Barcelona). Speleon, 12(1-2): 35-55. (in Spanish) ("Karst hypogeous forms study developed in the edge of the polje of Begues (Macizo del Garraf, Barcelona)”)

NASA 2016, NASA Visible Earth. 11 Aug. 2009. EOS Project Science Office. Retrieved 05 February 2016. URL: https://visibleearth.nasa.gov/

Núñez, M.A., Buill, F. \& Edo, M. 2013, 3D model of the Can Sadurní cave. Journal of Archaeological Science, 40(12): 4420-4428. doi:10.1016/j.jas.2013.07.006

Risch, R. 1995, Recursos naturales y sistemas de producción en el sudeste de la Península Ibérica entre 3000 y 1000 ANE. Doctoral thesis at Universitat Autònoma de Barcelona, Edición Microfotográfica, Barcelona, 601 p. (in Spanish) ("Natural ressources and production systems in the South eastern of Iberian Peninsula between 3000 and 1000 BCE”) URL: http://hdl.handle.net/10803/5524

Risch, R. \& Martínez Fernández, F. 2008, Dimensiones naturales y sociales de la producción de hachas de piedra en el noreste de la Península Ibérica. Trabajos de Prehistoria, 65(1): 47-71. (in Spanish) ("Natural and social dimensions of stone axes production in north eastern of Iberian Peninsula”) doi:10.3989/tp.2008.v65.i1.135

Roca Adrover, A. \& Miranda Canals, J. (Eds.) 2010, Atles Geològic de Catalunya. Institut Cartogràfic i Geològic de Catalunya, Barcelona, 463 p. (in Catalan) (“Geological atlas of Catalonia”)

Semenov, S.A. 1981, Tecnología prehistórica. Estudio de las herramientas y objetos antiguos a través de las huellas de uso. Akal, Madrid, 370 p. (in Spanish) ("Prehistoric tecnology. Ancient tools and artifacts study with the aid of use-wear traces")

Vilà, M. \& Pin, C. 2015, Geochemistry and Nd isotope signature of the Collserola Range Palaeozoic succesion (NE Iberia): Gondwana heritage and pre-Mesozoic geodynamic evolution. Geological Magazine, 153(04): 643-662. doi:10.1017/s0016756815000837 